\title{
Investigation on interaction of radiofrequency waves (microwaves) with saphenous veins
}

\author{
Karthik Baskar ${ }^{1}$ *, Pavithra Krishnamoorthy ${ }^{2}$, Nehrujee Vishalinee ${ }^{1}$, \\ Padmavarshini Sivakumar ${ }^{1}$, Anita ${ }^{1}$, Varshini Karthik ${ }^{2}$ \\ ${ }^{1}$ Assistant Professor Department of Biomedical Engineering, SRM Institute of Science and Technology, Kattankulathur \\ ${ }^{2}$ Head of the Department in-charge Department of Biomedical Engineering, SRM Institute of Science and Technology, Kattankulathur
}

\begin{abstract}
Varicose veins contract when heated through microwave ablation. Heat application through microwave ablation, the collagen tends to regain its elasticity. In this paper, we propose simulation of the varicose vein with a wearable micro strip patch antenna. ANSYS HFSS 17.2 is an electromagnetic finite element method solver. The phantom model of human skin with normal vein and varicose vein with a wearable micro strip patch antenna was designed using this software. The wearable micro strip patch antenna is designed so that this approach is minimally invasive. The wearable micro strip patch antenna is modelled with a resonant frequency of $9.8 \mathrm{GHz}$. The temperature of about $45^{\circ} \mathrm{C}$ is proposed as the treatment for varicose vein.
\end{abstract}

Keywords: SSV-Small Saphenous Vein; SAR-Specific Absorption Rate; S-Seconds; W/Kg-Watts per Kilogram; GHZ-Gigahertz; W-Watts; Mm-Millimetre; ${ }^{\circ} \mathrm{C}$-Degree Celsius.

\section{Introduction}

Varicose vein is an aberrance of a superficial vein. Varicose veins patients are present in $15 \%$ of men and $25 \%$ of woman. The commonness of this disease is due to family history, female hormones, arterial venous connections, physiological and biochemical stress. Varicose vein is generally treated surgically. The medical procedure takes forever and ever and large abrasion size. Varicose veins are caused in weak or damaged veins. After arteries and capillaries pass oxygenated blood throughout the body, veins return the blood to the heart, the veins in legs must work against gravity to do this. Hence there are valves inside the veins that open and let the blood flow through, and then they close to keep blood from flowing backwards. If these valves are weakened or damaged, blood can flow back and pool in the veins, this causes the veins to swell. Habitually, the walls of these veins are elastic (stretchy). When the valve flaps of these veins separate, blood can flow backward through the valves.

\subsection{Effect of collagen on varicose veins}

Collagen is the connective tissue that gives structural support to your body by binding cells or tissues together. Collagen is a protein that accounts for over one-fourth of all the protein in your body. More importantly, collagen is responsible for maintaining the elasticity and strength of your blood vessels. An imbalance between the synthesis of collagen I and collagen III explains the lack of elasticity of varicose veins.

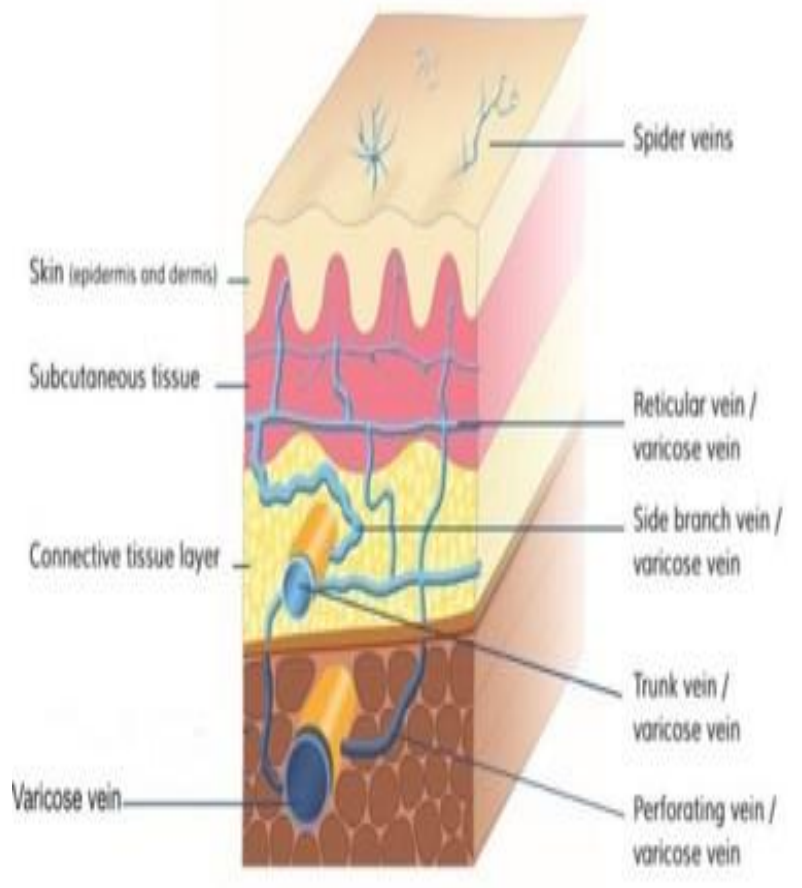

Fig. 1: Structure of Varicose Veins. 


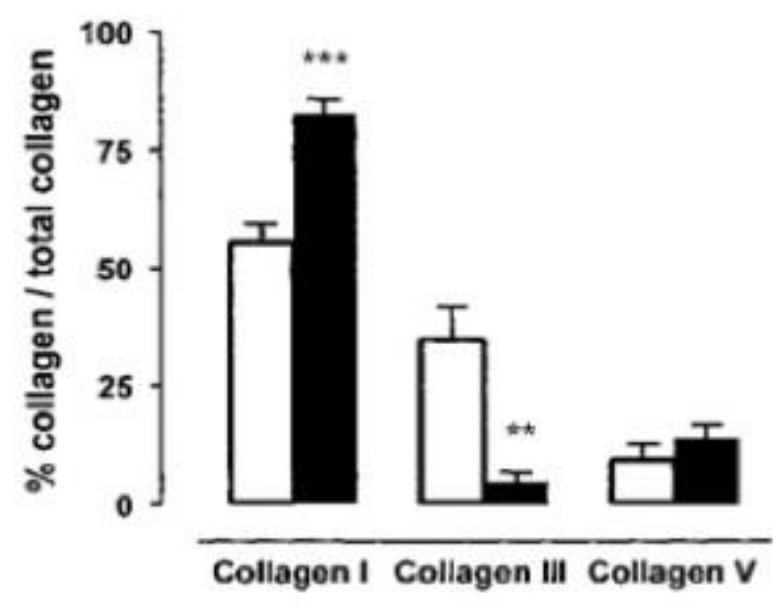

Fig. 2: Effect of Collagen.

\section{Methodology}

\subsection{Modelling of varicose veins}

The phantom model of varicose vein is designed using ANSYS HFSS 17.2 software. The cylindrical model has been designed for the human skin layers with normal and varicose veins. In this model, the blood vessel is the Small Saphenous vein (SSV) which is present between the hypodermis and subcutaneous tissue and a tributary of the SSV is present in the dermis layer of the skin. The dielectric properties of skin dry, blood vessel and subcutaneous tissue have been created in ANSYS HFSS 17.2 software for epidermis, dermis and hypodermis.

Table 1: Dielectric Properties of Skin Dry, Blood Vessel and Subcutaneous Tissues

\begin{tabular}{|c|c|c|c|c|}
\hline 3 & PROPERTIES & $\begin{array}{l}\text { SKIN } \\
\text { DRY }\end{array}$ & $\begin{array}{l}\text { BLOOD } \\
\text { VESSEL }\end{array}$ & $\begin{array}{l}\text { SUBCUTANEOUS } \\
\text { TISSUE }\end{array}$ \\
\hline 1. & $\begin{array}{l}\text { Relative permit- } \\
\text { tivity }\end{array}$ & 33.367 & 35.533 & 4.779 \\
\hline 2. & $\begin{array}{l}\text { Relative permea- } \\
\text { bility }\end{array}$ & 1 & 1 & 1 \\
\hline 3. & Bulk conductivity & $\begin{array}{l}5.6172 \\
\mathrm{~S} / \mathrm{m}\end{array}$ & $\begin{array}{l}0.42899 \\
\mathrm{~S} / \mathrm{m}\end{array}$ & $6.5686 \mathrm{~S} / \mathrm{m}$ \\
\hline 4. & $\begin{array}{l}\text { Dielectric loss } \\
\text { tangent }\end{array}$ & 0.38797 & 0.20687 & 0.42447 \\
\hline 5. & $\begin{array}{l}\text { Measured fre- } \\
\text { quency }\end{array}$ & $7.8 \mathrm{GHz}$ & $7.8 \mathrm{GHz}$ & $7.8 \mathrm{GHz}$ \\
\hline 6. & Mass density & $\begin{array}{l}1050 \\
\mathrm{~kg} / \mathrm{m} 3\end{array}$ & $\begin{array}{l}994 \\
\mathrm{~kg} / \mathrm{m} 3 \\
\end{array}$ & $1035 \mathrm{~kg} / \mathrm{m} 3$ \\
\hline
\end{tabular}

\subsection{Wearable micro strip patch antenna}

Micro strip patch antenna is becoming eventually used because they are imprinted directly onto a circuit board. The antenna which is used for our purpose is wearable micro strip patch antenna. The patch antenna, micro strip transmission line and ground plate are made up of high conductivity metal (typically copper).The main advantage of wearable antennas is that they are drafted as elements of clothing able to transmit or receive wireless signals. The wearable antenna system plays an important role in many fields, including tracking and exploration. The wearable micro strip patch antenna is designed with various resonant frequencies such as $3.3 \mathrm{GHz}, 6.4 \mathrm{GHz}, 9.8 \mathrm{GHz}$ and $14 \mathrm{GHz}$.

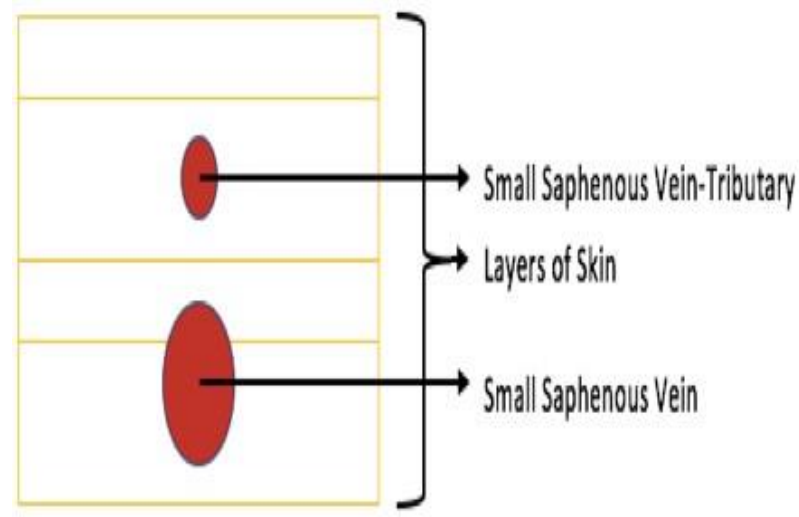

Fig. 3: Design of Varicose Vein-1.

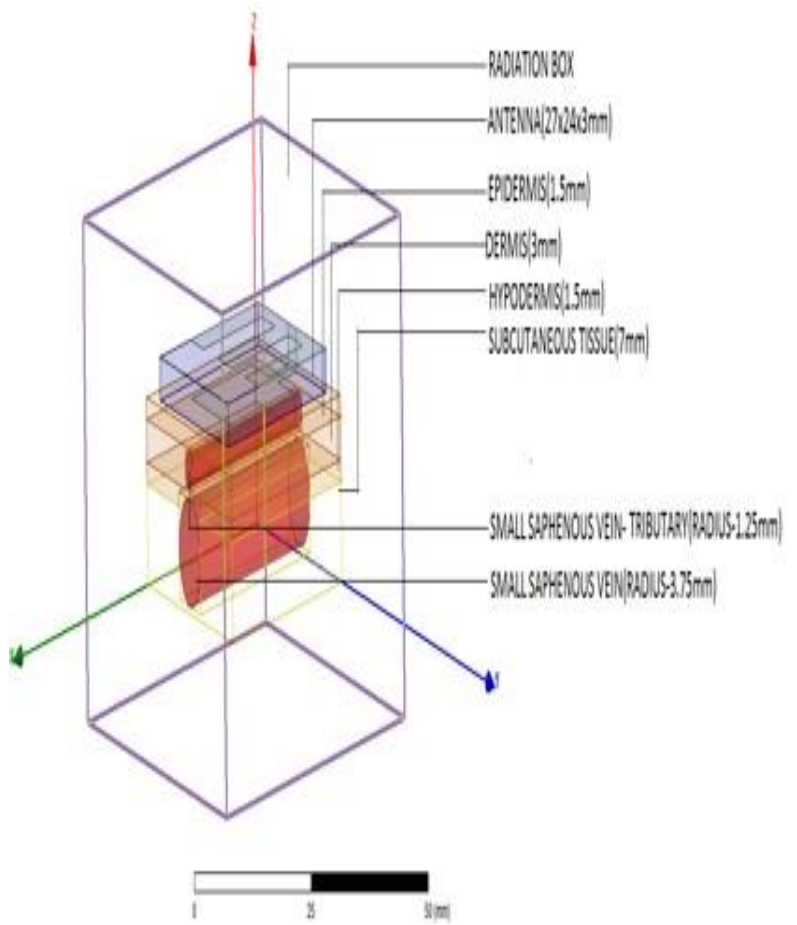

Fig. 4: Design of Varicose Vein-2.

Table 2: Design Parameters of Normal \& Varicose Vein

\begin{tabular}{|c|c|c|c|c|}
\hline $\begin{array}{l}\text { S. } \\
\text { No. }\end{array}$ & LAYERS & PROPERTIES & $\begin{array}{l}\text { NORMAL } \\
\text { VEIN } \\
\end{array}$ & $\begin{array}{l}\text { VARICOSE } \\
\text { VEIN }\end{array}$ \\
\hline 1. & Epidermis & Skin dry & $1.5 \mathrm{~mm}$ & $1.5 \mathrm{~mm}$ \\
\hline 2. & Dermis & Skin dry & $1.5 \mathrm{~mm}$ & $1.5 \mathrm{~mm}$ \\
\hline 3. & $\begin{array}{l}\text { Tributary- } \\
\text { SSV }\end{array}$ & $\begin{array}{l}\text { Blood Ves- } \\
\text { sel(Radius) }\end{array}$ & $0.65 \mathrm{~mm}$ & $1.25 \mathrm{~mm}$ \\
\hline 4. & Hypodermis & Skin dry & $1.5 \mathrm{~mm}$ & $1.5 \mathrm{~mm}$ \\
\hline 5. & $\begin{array}{l}\text { Small Saphe- } \\
\text { nous Vein }\end{array}$ & $\begin{array}{l}\text { Blood Ves- } \\
\text { sel(Radius) }\end{array}$ & $4 \mathrm{~mm}$ & $3.75 \mathrm{~mm}$ \\
\hline 6. & $\begin{array}{l}\text { Subcutaneous } \\
\text { Tissue }\end{array}$ & $\begin{array}{l}\text { Subcutaneous } \\
\text { Tissue }\end{array}$ & $4 \mathrm{~mm}$ & $7 \mathrm{~mm}$ \\
\hline
\end{tabular}

\subsection{Design parameters of wearable microstrip patch antenna}

1) Width (W)

The width of the patch is reckoned using the following formula, Equation 1 Width of the Patch 


$$
W=\frac{c_{0}}{2 f_{r}} \sqrt{\frac{2}{\varepsilon_{r}+1}}
$$

Where,

$W=$ Width of the patch

$C_{0}=$ Speed of light

$\varepsilon_{r}=$ value of the dielectric substrate

2) Effective Refractive Index:

The effective refractive index value of a patch is an important criteria in the making of a micro strip patch antenna. The radiations enrooted from the patch towards the ground travel through air and substrate this effect is known as fringing effect. Both the air and substrates have different dielectric values, therefore to account for this, we find the effective dielectric constant. The value of the effective dielectric constant $\left(\mathcal{E}_{\text {reff }}\right)$ is calculated using the following formula,

Equation 2 Effective Refractive Index

$$
\varepsilon_{\text {reff }}=\frac{\varepsilon_{r}+1}{2}+\frac{\varepsilon_{r}-1}{2}\left[1+12 \frac{h}{W}\right]^{-1 / 2}, W / h>1
$$

Where,

$\varepsilon_{r}=$ value of the dielectric substrate

$\mathrm{h}=$ height of the substrate

$\mathrm{W}=$ width of the substrate

3) Length (L)

Due to fringing effect, electrically the length of the antenna is increased by an amount of L. Therefore, the actual increase in length $(\mathrm{L})$ of the patch is to be calculated using the following formula,

Equation 3 Length of the Patch

$$
L=\frac{C_{0}}{2 f_{r} \sqrt{\varepsilon_{r e f f}}}-2 \Delta L
$$

4) Length ( $\mathrm{Lg})$ and Width (Wg) of Ground Plate

The length and width of a substrate are equal to that of the ground plate. The length of a ground plate $(\mathrm{Lg})$ and the width of a ground plate $(\mathrm{Wg})$ is calculated using the following equations,

Equation 4 Length and width of Ground Plate

$$
L_{g}=6 h+L
$$

$W_{\circ}=6 h+W$

5) The width of the Microstrip Transmission Line The width of Transmission line (TL) is given by the following formula,

Equation 5 Width of Transmission Line

$$
\mathrm{TL}=\underline{\lambda}=\underline{\lambda 0}
$$$$
4 \quad 4 \sqrt{\varepsilon} r
$$

\subsection{Substrate}

Generally, for micro strip antennas, the substrate's dielectric constants ranges from 2.2 to 12 . Here we have chosen different cotton textiles like jean cotton, wash cotton, polycotton and certain cotton as substrates. The radiation parameters greatly depend on the substrate hence must be chosen carefully. The substrate which we have used is wash cotton. The properties of wash cotton are given in table 3 .

\subsection{Design of the micro strip patch antenna}

The design of micro strip patch antenna comprises of the radiating patch, transmission line, substrate and the ground plate. The radiating patch is a two-dimensional structure constructed with the dimensions of $16.7 \mathrm{mmx} 15 \mathrm{~mm}$ with the property of Copper/Perfect E. The transmission line is a two-dimensional structure constructed with the dimensions of $5.15 \mathrm{mmx} 3.1 \mathrm{~mm}$ with the property of Copper/Perfect E. The substrate is a three-dimensional structure of the dimensions of $27 \mathrm{~mm} \times 24 \mathrm{~mm} \times 3 \mathrm{~mm}$ with the properties of wash cotton. The ground plate is a two-dimensional structure with the properties of Copper/Perfect E. Different types of ground plates were tried for the antenna and the required frequency response was only obtained by etching the structure $\mathrm{E}$ in the ground plate. The wearable micros trip patch antenna has been designed for both saphenous veins (normal and varicose).

Table 3: Dielectric Properties of Substrate

\begin{tabular}{lll}
\hline \multicolumn{3}{c}{ Table 3: Dielectric Properties of Substrate } \\
\hline S. No. & PROPERTIES & VALUES \\
\hline . & Relative permittivity & 1.51 \\
3. & Relative permeability & 1 \\
4. & Bulk conductivity & 0 \\
5. & Dielectric loss tangent & 0.02 \\
6. & Measured frequency & $7.8 \mathrm{GHz}$ \\
\hline
\end{tabular}

Table 4: Design Parameters of the Wearable Microstrippatch Antenna

\begin{tabular}{lll}
\hline S. No. & Design Properties & Dimensions \\
\hline 1. & Length of the patch & $16.7 \mathrm{~mm}$ \\
2. & Width of the patch & $15 \mathrm{~mm}$ \\
3. & Length of the substrate & $27 \mathrm{~mm}$ \\
4. & Width of the substrate & $24 \mathrm{~mm}$ \\
5. & Height of the substrate & $3 \mathrm{~mm}$ \\
6. & Width of transmission line & $3.1 \mathrm{~mm}$ \\
\hline
\end{tabular}

\section{Analysis}

In this study, we are analyzing all the parameters mentioned below: • Specific Absorption Rate $\bullet$ Temperature $\bullet$ Time period for the radiation to occur $\bullet$ Power level. The maximum temperature that a human body can resist is $45^{\circ} \mathrm{C}$. We also use $45^{\circ} \mathrm{C}$ of temperature by varying the time period of radiation occurred in the body.

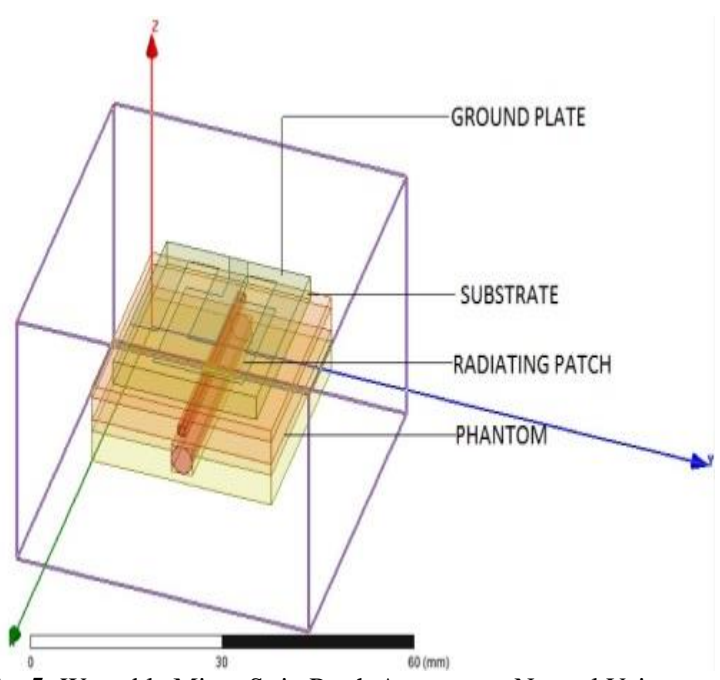

Fig. 5: Wearable Micro Strip Patch Antenna on Normal Vein. 


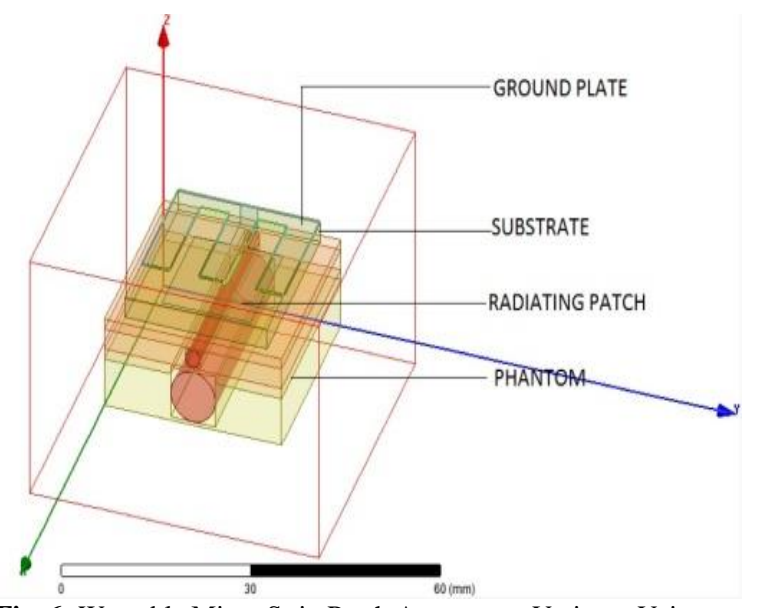

Fig. 6: Wearable Micro Strip Patch Antenna on Varicose Vein.

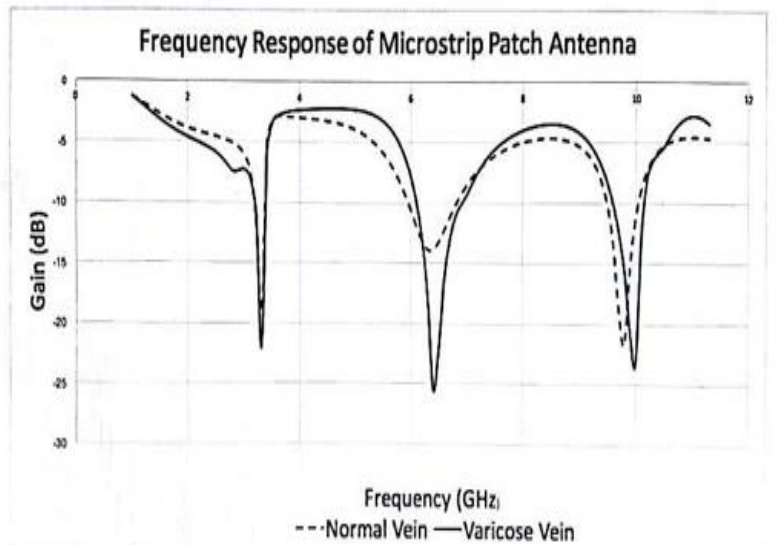

Fig. 7: Frequency Response of the Wearable Micro Strip Patch Antenna.

\subsection{Specific absorption rate}

Specific absorption rate (SAR) is a measured as the rate of energy that is a absorbed by the human body when exposed to a radio frequency (RF) electromagnetic radiation.SAR is usually averaged either over the whole body or over a small sample of tissue (typically $1 \mathrm{~g}$ or $10 \mathrm{~g}$ of tissue). Its unit is $\mathrm{W} / \mathrm{kg}$. The formula for SAR is given below,

Equation 6 Specific Absorption Rate

$$
\mathrm{SAR}=\frac{1}{V} \int_{\text {sample }} \frac{\sigma(\mathbf{r})|\mathbf{E}(\mathbf{r})|^{2}}{\rho(\mathbf{r})} d \mathbf{r}
$$

\subsection{Temperature}

It is the amount of heat absorbed by the tissue for a particular time period. Its unit is ${ }^{\circ} \mathrm{C}$. The amount of heat required to penetrate electromagnetic waves in the tissue is $45^{\circ} \mathrm{C}$. The temperature for a short period of time (fig.8) and a long period of time (fig.9) are given in formula below,

Equation 7 Temperature

$$
\begin{aligned}
& \Delta T=S A R \cdot \frac{\Delta t}{c} \\
& T \max =\frac{q}{\lambda^{\prime}}\left[1-\left(\sqrt{\lambda^{\prime}} A+1\right) e^{-\sqrt{\lambda \cdot}}\right]
\end{aligned}
$$

\subsection{Time period}

The duration for which the electromagnetic waves have been penetrated to the tissue to acquire a temperature of $45^{\circ} \mathrm{C}$. Its unit is seconds (sec).This can be changed by varying the power level for a given tissue.

\subsection{Power level}

Power is the rate at which electromagnetic energy is generated or consumed in a particular time period. It is measured in Watts (W). The power conversion is given in the formula below, Equation 8 Power Level

$$
1 \mathrm{~W}=1 \frac{\mathrm{J}}{\mathrm{s}}=1 \frac{\mathrm{N} \cdot \mathrm{m}}{\mathrm{s}}=1 \frac{\mathrm{kg} \cdot \mathrm{m}^{2}}{\mathrm{~s}^{3}}
$$

\subsection{Analysis of normal vein}

The SAR Distribution is shown in fig. 10 and the various SAR distributions for various power levels are tabulated in Table V.

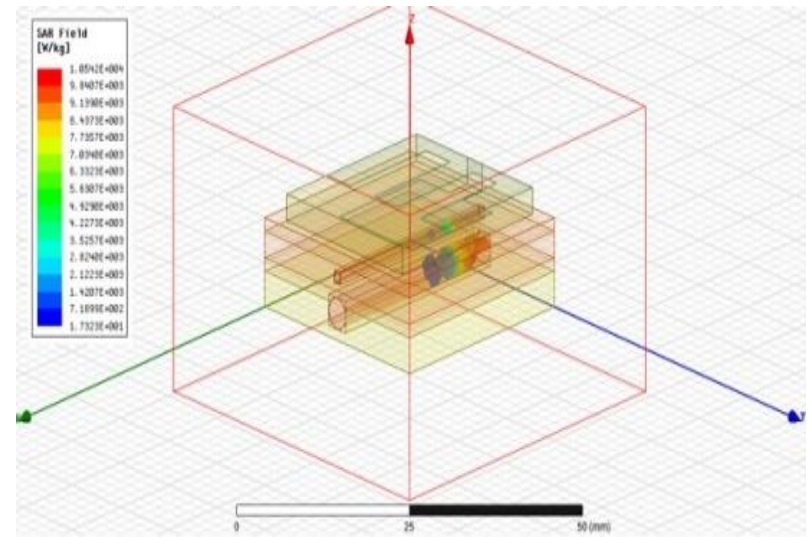

Fig. 8: SAR Distribution Normal Vein

Table 5: SAR Distribution of Normal Vein

\begin{tabular}{lllll}
\hline S. No. & $\begin{array}{l}\text { SAR } \\
(\mathrm{W} / \mathrm{Kg})\end{array}$ & Temperature $\left({ }^{\circ} \mathrm{c}\right)$ & Power $(\mathrm{W})$ & Time $(\mathrm{S})$ \\
\hline 1. & 2108.5 & 45.311 & 10 & 75 \\
2. & 4216.9 & 44.993 & 20 & 38 \\
3. & 6325.4 & 45.310 & 30 & 25 \\
4. & 8433.9 & 45.311 & 40 & 18.75 \\
5. & 10542 & 45.309 & 50 & 15 \\
\hline
\end{tabular}

\subsection{Analysis of varicose vein}

The SAR Distribution is shown in fig. 11 and the various SAR distributions for various power levels are tabulated in Table 6 .

Table 6: SAR Distribution of Varicose Vein

\begin{tabular}{lllll}
\hline S. No. & SAR $(\mathrm{W} / \mathrm{Kg})$ & Temperature $\left({ }^{0} \mathrm{c}\right)$ & Power $(\mathrm{W})$ & Time $(\mathrm{S})$ \\
\hline 1. & 2618.7 & 45.349 & 10 & 73 \\
2. & 5237.3 & 45.019 & 20 & 30 \\
3. & 7856 & 45.020 & 30 & 20 \\
4. & 10475 & 45.028 & 40 & 15 \\
5. & 13093 & 45.037 & 50 & 12 \\
\hline
\end{tabular}

where,

$q=\frac{\rho S}{K} ; \quad \lambda^{\prime}=\frac{w c_{b}}{K} ; A=\frac{\lambda}{4}$ 


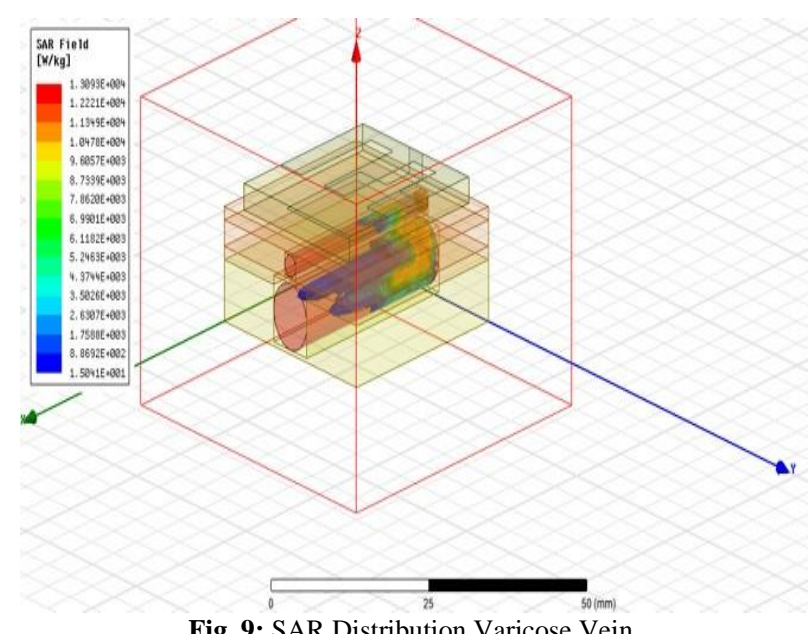

Fig. 9: SAR Distribution Varicose Vein.

\section{Discussions}

As the SAR increases in the saphenous veins, the temperature also increases. This is because of the fact that the increasing amount of radiation in the tissue causes heating at a faster rate. When the amount of heat in the tissue is higher, the time required to regain the elasticity of the collagen in the saphenous vein will also increase. The amount of heat transferred into a tissue (per kg) is the SAR (average) of the saphenous vein. As the density of the tissue increases, the power level of tissue will tend to decrease. Table VII shows the observations between normal and varicose veins for the various parameters that have been analysed.

\section{Conclusion}

In this varicose vein therapy, using finite element analysis, an antenna is sketched out as a wearable micro strip patch antenna. Antenna controls the heat that radiates to the tissue. The tissue is heated then the size of the varicose vein is reduced and the vein is straightened. The results of simulation and analysis by using ANSYS HFSS 17.2 software- the microwave frequency is defined to $9.8 \mathrm{GHz}$ with SAR distribution is $13093 \mathrm{~W} / \mathrm{kg}$ to obtain a temperature of $45.037^{\circ} \mathrm{C}$ and the time taken for the antenna to achieve this temperature is 12 seconds. Varicose vein therapy by using microwave ablation is a new surrogate manoeuvre for the patient and hopefully may reduce the use of medicines and help in varicose vein treatment in the future.

Table 7: SAR Distribution, Temperature and Time for Normal and Varicose Veins for Various Power Levels

\begin{tabular}{lllllll}
\hline $\begin{array}{l}\text { Power } \\
\text { Level } \\
(\mathrm{W})\end{array}$ & $\begin{array}{l}\text { Sar Normal Vein } \\
(\mathrm{W} / \mathrm{Kg})\end{array}$ & $\begin{array}{l}\text { Sar Varicose Vein } \\
(\mathrm{W} / \mathrm{Kg})\end{array}$ & $\begin{array}{l}\text { Temp Normal } \\
\text { Vein }\left({ }^{\circ} \mathrm{C}\right)\end{array}$ & $\begin{array}{l}\text { Temp Varicose } \\
\text { Vein }\left({ }^{\circ} \mathrm{C}\right)\end{array}$ & $\begin{array}{l}\text { Time Normal } \\
\text { Vein }(\mathrm{S})\end{array}$ & $\begin{array}{l}\text { Time Varicose } \\
\text { Vein }(\mathrm{S})\end{array}$ \\
\hline 10 & 2108.5 & 2618.7 & 45.311 & 45.349 & 75 & 73 \\
20 & 4216.9 & 5237.3 & 44.993 & 45.019 & 38 & 30 \\
30 & 6325.4 & 7856 & 45.310 & 45.020 & 25 & 18.75 \\
40 & 8433.9 & 10475 & 45.311 & 45.028 & 15 & 15 \\
50 & 10542 & 13093 & 45.309 & 45.037 & 15 & 12 \\
\hline
\end{tabular}

\section{References}

[1] S. Prasantamrongsiri, P. Phasukkit, C. Pintavirooj, S. Tungjitkusolmun, A.Sanpanich, "3D Finite Element Analysis for Varicose Vein Therapy by Using Microwave Ablation", The 2012 Biomedical Engineering International Conference (BMEiCON-2012). https://doi.org/10.1109/BMEiCon.2012.6465480.

[2] Tamar Nijsten, Renate R. van den Bos, Mitchel P. Goldman, Michael A. Kockaert, Thomas M. Proebstle Eberhard Rabe, Neil S. Sadick, Robert A. Weiss, Martino H.A. Neumann, "Minimally invasive techniques in the treatment of saphenous varicose veins", JAAD. 2009; 60:110-9. https://doi.org/10.1016/j.jaad.2008.07.046.

[3] S SUBRAMONIA, TA LEES, "The treatment of varicose veins", Ann R Coll Surg Engl 2007.s

[4] Stephen J Goodyear, Isaac K Nyamekye, "Radiofrequency ablation of varicose veins: Best practice techniques and evidence", 2015, Vol. 30(2S) 9-17 Phlebology.

[5] M A Anwar, T R A Lane, A H Davies, I J Franklin, "Complications of radiofrequency ablation of varicose veins", 2012; 27 Suppl 1:3439 Phlebology.

[6] Chaitali Ingale, Trupti Ingale, Anand Trikolikar, "Study of Different Types of Microwave Antenna and Its Applications”, Special Issue, March-April 2013, Volume-3.

[7] Eng Gee Lim, Zhoa Wang, Jing Chen Wang, Mark Leach, Rong Zhou, Chi-un Lei, Ka Lok Man, Wearable Textile Substrate Patch antennas, IEEE

[8] Liton Chandra Paul, Nahid Sultan, Design Simulation Performance Analysis of a Line Feed rectangular Microstrip Patch Antenna, International Journal of Engineering Sciences \& Emerging Technologies

[9] https://www.everythingrf.com/rf-calculators

[10] https://www.pasternack.com/t-rf-microwave-calculators-andconversions.aspx

[11] Varshini Karthik, T.Rama Rao, Investigations on SAR and Thermal Effects of a Body Wearable Microstrip Antenna, Springer 2017.

[12] T. Padmapriya and V.Saminadan, "Improving Performance of Downlink LTE-Advanced Networks Using Advanced Networks
Using Advanced feedback Mechanisms and SINR Model", International Conference on Emerging Technology (ICET), vol.7, no.1, pp: 93, March 2014.

[13] S.V.Manikanthan and T.Padmapriya "Recent Trends In M2m Communications in $4 \mathrm{~g}$ Networks and Evolution towards $5 \mathrm{~g}$ ", International Journal of Pure and Applied Mathematics, ISSN NO: 1314-3395, Vol-115, Issue -8, Sep 2017.

[14] N Bala Dastagiri, K Hari Kishore "Novel Design of Low Power Latch Comparator in 45nm for Cardiac Signal Monitoring”, International Journal of Control Theory and Applications, ISSN No: 0974-5572, Vol No.9, Issue No.49, page: 117-123, May 2016. 